\title{
Failed Collaborative Efforts Relating to Public Lands Use in Idaho's Boulder-White Cloud Mountains Area
}

\author{
E. Scott Lee \\ Assistant Professor, Political Science, Indiana University East \\ 252 Tom Raper Hall, 2325 Chester Blvd., Richmond, IN 47374, USA \\ Tel: 765-973-8324Ｅ-mail: scottlee@iue.edu
}

Received: May 17, 2017 Accepted: June 21, 2017

doi:10.5296/emsd.v6i2.11237 URL: https://doi.org/10.5296/emsd.v6i2.11237

\begin{abstract}
U.S. Representative Mike Simpson touted his collaboration efforts regarding the Central Idaho Economic Development and Recreation Act (CIEDRA). He stated he had worked hard to bring together different stakeholders representing local ranchers, local, state, and federal government officials, recreationists, wilderness proponents, and other interested groups and individuals to work toward resolving the public land use issues facing the Boulder-White Clouds area in Central Idaho. On its face it appeared to be a perfect example of collaborative decision making. Yet, CIEDRA failed every time it was introduced in Congress. Analysis of the process utilized by Simpson reveals that the CIEDRA collaboration was unsuccessful because there was, in fact, no collaboration. The necessary steps for collaborative decision making were not followed and ultimately, when resistance to the collaborative efforts was encountered early on in the process, a conscious switch was made to "shuttle diplomacy" which was ultimately unsuccessful.
\end{abstract}

Keywords: Collaborative decision making, CIEDRA, Collaboration, Simpson, Boulder-White Clouds

\section{Introduction}

Mike Simpson (R-ID) began his collaborative efforts to pass CIEDRA (Central Idaho Economic Development and Recreation Act) shortly after being elected in 1998 to the U.S. House of Representatives. He was concerned that lawsuits filed against ranchers operating in the Boulder-White Cloud Mountains area (Boulder-White Clouds) inhibited their ability to operate. He "agreed to bring together county commissioners, recreationists, and conservationists to find long-term stability for all interested parties in the face of serious land management conflicts in this area" (Simpson, 2010, n.p.). Simpson's collaborative efforts 
from that time until 2014 were taken "with the ultimate goal of clarifying and solidifying current public uses of the area and removing the uncertainty of future uses" (Lee, 2015, n.p.). Yet, Simpson was unsuccessful even though he introduced CIEDRA in every congressional session between 2004 and 2013. His collaborative efforts for CIEDRA provide a roadmap of what not to do when organizations attempt collaboration for intractable environmental problems.

\section{Background}

The Boulder-White Clouds area, long considered a treasured gem in the Gem State, is located in Central Idaho and covers approximately 500,000 acres. Numerous animal species, including endangered species are found in the area. It is considered a premier recreational venue and is "prized by outdoor enthusiasts, including wilderness proponents, motorcyclists, mountain bikers, ATV riders, snowmobilers, skiers, snowshoers, hikers, backpackers, horsemen, and fishermen" (Lee, 2015, n.p.). Numerous ranchers graze cattle in the area, with historic cattle grazing going back six generations. All of these uses are included in the 66 licensed activities in the Boulder-White Clouds.

Approximately half of the area was designated a Wilderness Study Area as part of the 1972 Sawtooth National Recreation Act. Before 2015, Idaho had approximately 4,521,206 acres designated as wilderness by seven legislative acts. This amount constitutes $8.5 \%$ of the approximately 52.9 million total acres in the state. Under CIEDRA approximately 332,928 more acres would have become wilderness and approximately 131,616 acres that had been part of the 1972 Wilderness Study Area would be released from the wilderness study directive. Unfortunately, wilderness is a controversial and divisive topic in Idaho. Some believe that more wilderness is necessary to protect the area, while others are adamant that there is already enough, if not too much, wilderness in the state.

With the many disparate and contradictory uses in the area, there existed an intractable or "wicked" dispute over those uses, one which Simpson worked to resolve. It is through a persistent, carefully orchestrated, collaborative decision making process that there exists a methodology with a chance to resolve this type of wicked public land use disputes. This article analyzes Simpson's failure to successfully use such a process in his attempts to secure passage of CIEDRA. ${ }^{\mathrm{i}}$

\section{Literature Review}

Many public lands use disputes are deemed to be "intractable" or "wicked" in nature (Ludwig, Mangel, \& Haddad, Brent, 2001; McBeth \& Shanahan, 2004; Rittel \& Webber, 1973). "Wicked problems come about when social problems are so complex that people disagree about problem definition and solution, and uncertainty about future environmental resources and differences in social values makes it practically impossible to define appropriate solutions" (Lee, 2015, citing to Chapin, Trainor, Huntington, Lovecraft, Zavaleta, Natcher et al., 2008; Gunderson, 1999; and Shindler \& Cramer, 1999). Competing visions for future environmental issues (Hurley \& Walker, 2004), differing values or core beliefs (Gregory, Failing, Harstone, Long, McDaniels, \& Ohlson, 2012), and conflicting priorities or 
competing economic interests (Schmidtz, 2000) may all give rise to wicked problems. McBeth and Shanahan (2004) posit that in wicked problems the political discourse moves from robust deliberations into policy marketing efforts by competing stakeholders or policy entrepreneurs resulting in a lose-lose process where policies remain contested.

Discourse alone is insufficient to address wicked problems. They may, however, be resolved through collaborative decision making, defined herein as the application over time of objective decision making and group deliberation methods in a collaborative and facilitative manner to understand complex problems and generate and evaluate creative alternatives for their resolution. It involves transcendent discourse in which an emergent shared language is created through which the parties can bridge their differences (Pearce \& Littlejohn, 1997), where all participants attempt in good faith to meet the interests of all stakeholders (van de Kerkhof, 2006). It is a democratic problem-solving approach that acknowledges the pluralistic, social nature of the problem and progress, where it is believed that everyone that comes to the table has something to offer and to learn (Abigail \& Cahn, 2011; Clemons \& McBeth, 2009) and where parties' values are not only acknowledged, but are part of the discussion (Gregory et al., 2012; Keeney, 1992). It is a process encompassed by democratic values (McBeth, Lybecker, \& Garner, 2010) where individuals meet "repeatedly over time and work side-by-side to build a common understanding of complex issues and create implementable win-win solutions through an interactive, iterative, and reflexive process, all while building trust and allaying fears, anxiety, and hostility, thinking comprehensively about the problem, learning mutually from other participants, gaining legitimacy of decisions, breaking gridlocks, and avoiding litigation (Lee, 2015, n.p., citing to Daniels and Walker, 2001; Gregory et al., 2012; Irvin \& Stansbury, 2004; Rutherford, Gibeau, Clark, \& Chamberlain, 2009; and Stevens, 2006).

Collaborative decision making is not, however, without barriers. The list of tricks that can be used to prevent collaborative discussion is long and varied (Abigail \& Cahn, 2011; Clemons \& McBeth, 2009; Fisher \& Ury, 1991). Weber and Khademian (2008) identify additional impediments. First, long-standing adversaries must be willing to share information that would typically be hidden. While this may lead to innovative and better solutions, shared information may also be used by participants that withdraw from the process for their own advantage. Second, the shape of the final agreement is less predictable as the realm of information grows. Finally, there is nothing to prevent participants from falling back on the tried-and-true methods of litigation, public relations campaigns, and appeal to governmental officials with the ability to override the agreed-upon resolution. For collaboration to work, stakeholders must agree to not go outside the collaborative venue for issue resolution.

While scholars differ over individual actions to be taken and their exact order, all agree there are various steps to take in the collaborative decision making process, either preparatory or participatory. The preparatory step includes identifying and clarifying the context within which the decision is to be made. The participatory steps include determining the objectives and values of the stakeholders, defining the performance measurements for analyzing and comparing alternatives, developing and analyzing alternatives, identifying and evaluating value trade-offs between alternatives, and selecting, implementing, monitoring, reviewing, 
and evaluating the chosen alternative. In collaborative decision making, the participatory steps involve active, continual joint participation over time by stakeholders.

\subsection{Preparatory Step - Identifying and Clarifying the Context}

The individual or group in charge of the collaborative decision making efforts (e.g., facilitator, organizer, instigator) undertakes a broad overview of the process before beginning to determine the scope of the issue and to create the appropriate collaborative process itself. This consists of a quick, overarching review of the first few steps of the collaborative decision making process and typically involves initial issue definition, identifying stakeholders to participate in the process, considering the timing for the decision, identifying the initial range of possible objectives, alternatives, and types decisions to be made, identifying possible analytical tools that might be used, and considering possible levels and types of consultation needed in the process.

Rochefort and Cobb (1993) posit that issue definition is fundamental to policy making. Issue definition encompasses the "processes by which an issue (problem, opportunity, or trend), having been recognized as such and placed on the public policy agenda, is perceived by various interested parties; further explored, articulated, and possibly quantified; and in some but not all cases, given an authoritative or at least provisionally acceptable definition in terms of its likely causes, components, and consequences" (Hogwood \& Gunn, 1984, p. 109).

The manner in which an issue is defined affects participants' perceptions of the issue and influences their action or inaction (Stone, 2002). Thus, a decision to allow stakeholders to participate in the issue definition process or to have the facilitator define the issue may be determinative as to the solution. Not allowing stakeholders to participate in defining the issue may impede the basic tenant of consensus building that participating stakeholders must have a sense of ownership of the process (Carpenter, 1999).

At its very basic level, every American is a stakeholder in public lands use policies. More directly affected, however, are those whose livelihoods or missions are positively or negatively influenced by policy such as ranchers, outdoors enthusiasts, environmental groups, wilderness proponents, and resource extractors. These groups can be deemed a necessary "critical mass" (Schmitt 2011). Questions that identify those whose support for implementation is needed, who control resources, who have traditionally been involved in the issue, who have expertise regarding the issue, and who would grant legitimacy to the process, should be asked and answered (Clemons \& McBeth, 2009). If those who should be there are not or those who need not be there are included, collaborative efforts may come to naught. Thus, it is necessary to perform an in-depth stakeholder analysis to determine who the stakeholders are, who should be included in the collaboration, their respective positions on the issue, the power they have, their stance on the issue, influence by and on each stakeholder, and other relevant characteristics that may impact the collaborative efforts. Further, such an analysis is helpful because in the U.S. policy system, stakeholders have numerous opportunities to approach alternate policy arenas as a result of separation of powers, overlapping jurisdictions, and easy access to different types and levels of policymakers (Pralle, 2006). 
Methods to identify and gauge stakeholders can include the "power versus interest" grid (Bryson, Cunningham, \& Lokkesmoe, 2002; Eden \& Ackermann, 1998), the "stakeholder influence" diagram (Bryson el al., 2002; Eden \& Ackermann, 1988; Finn 1996), the "Bases of Power - Directions of Interest" diagram (Bryson et al., 2002), and the stakeholder map (Clemons \& McBeth, 2009).

Various conceptual frameworks attempt to explain timing, and the success or failure of those attempting policy change. Three such frameworks include Three (or Multiple) Streams Theory (Boscarino, 2009; Kingdon, 1984; Zahariadis, 2007), the Advocacy Coalition Framework (Sabatier \& Jenkins-Smith, 1988; Sabatier \& Jenkins-Smith, 1993; Sabatier \& Jenkins-Smith, 1999; Sabatier \& Weible, 2007), and Punctuated Equilibrium (Baumgartner \& Jones, 1993; True, Jones, \& Baumgartner, 2007) Each of these theories provides a frame for analyzing the occurrence and timing for public lands use policy making and are in agreement that if the timing is not right, policy change is doubtful.

In this broad overview an estimate of possible stakeholder objectives, alternatives, types of decisions, and the different analytical tools available to assist in the collaborative decision making are identified by the facilitator. Gregory and his colleagues (2012), Clemons and McBeth (2009), and Bardach (2009) provide between them a fairly comprehensive list of analytical tools that might be utilized, recognizing that not all tools may be applicable for any given situation. Identifying the possible tools allows advance preparation for the analysis steps in the process. Finally, by undertaking this broad overview, the probable levels and types of consultation can also be identified, both expert and non-expert.

\subsection{Participatory Steps}

It is principally during the participatory steps that stakeholders work together, over time, to create the necessary trust and synergy for creative solutions to wicked problems. During this part of the process objectives and values of stakeholders are defined, performance measures are determined, alternatives are developed, analyzed, and selected, with selected alternatives being subsequently implemented, monitored, reviewed, and evaluated.

Objectives are concise statements of the things that matter to the stakeholders while values are the underlying principles used for evaluation purposes (Gregory et al., 2012; Keeney, 1992). Domenici and Littlejohn (2001) refer to these as positions (the "whats") and interests (the "whys"), both of which are necessary to understand. Objectives are always context specific and are defined for the purpose of that particular issue. Failure to have the right stakeholders involved in the process may result in failure to obtain a comprehensive listing of all objectives and values (Keeney, 1992).

After obtaining the list of objectives and values, performance measures are defined. A performance measure is a "specific metric that can be used to consistently estimate and report the anticipated consequences of a management alternative with respect to a particular objective," and to specifically predict performance of alternatives for the purpose of choosing among alternatives (Gregory et al., 2012, p. 94). It is important that stakeholders play a part in performance measure selection (Clemons \& McBeth, 2009; Dunn, 2004; Gregory et al., 
2012; Keeney, 1992) and that they honestly compile the list of measures, rank them, and openly deal with the values that will come into play at this stage (Clemons \& McBeth, 2009; Keeney, 1992). Once performance measures are determined, alternatives can be developed and analyzed.

Alternatives are complete solutions to an issue or problem that can be compared by the decision makers in the decision making process and have three main properties (Gregory et al., 2012). First, they explore creative and new ways to achieve the objective; second, they expose and focus attention on value-based trade-offs; and finally they give the decision makers actual, meaningful choices to make. Good alternatives are developed iteratively, and are complete and comparable, value-focused, fully specified, internally coherent, distinct, and provide a meaningful solution (Gregory et al., 2012; Keeney, 2002). After creating and analyzing alternatives, an alternative is selected.

A major portion of the alternative selection process involves trade-offs. Because of the myriad of interests at play in public lands use issues, value trade-offs are inevitable. Multiple objectives and alternatives help deliver a difference balance across objectives, and trade-offs "involve making judgments about how much you would give up on one objective in order to achieve gains on another objective" (Gregory et al., 2012, p. 209). Collaboration goals should include avoiding unnecessary trade-offs by iteratively developing win-win alternatives, exposing unavoidable trade-offs and promoting constructive dialogue about them, making trade-offs explicit and transparent, and creating a basis for communicating a decision's underlying rationale (Gregory et al., 2012).

Signs of deliberative quality in the alternative selection process include participants being able to demonstrate an understanding of the decision scope and context, how it relates to other decisions, why it is important, and who is concerned about the consequences; having an understanding of the alternatives, their relative performance, and the key trade-offs made between the alternatives; and having an understanding of the key uncertainties and how they affect the performance of the alternatives (Gregory et al., 2012).

Effective collaborative decision making requires a group of stakeholders willing to invest in a process that may take many meetings over a substantial time period (Gregory et al., 2012). Even though stakeholders typically do not participate in policy implementation, as the group works together, trust can be generated, and a desire to continue to work together may be created (Thomson, Perry, \& Miller, 2009). Collaborative discourse, in collaborative relationships that have built up trust over continued meetings, can help participants break down stereotypes and frames, and develop new, positive working relationships grounded in trust (Stevens, 2006). Considering that public land use issues may change over time based upon changing circumstances, it makes sense for the group to continue to work together to monitor, evaluate, and review the decision made.

\section{Methodology}

In Pralle's 2006 book, Branching Out Digging In - Environmental Advocacy and Agenda Setting, she describes a qualitative approach to analyzing environmental decision making. 
Among other things, she outlines a format for interviewing participants in such decision making processes. Following Pralle's qualitative methodology, participants in Simpson's collaborative efforts were interviewed. Interview questions were created for each of the three different categories of interviewees. The first was for the two staff members from Simpson's office who were instrumental in the collaboration process. These were Lindsay Slater ("Slater"), Simpson's Chief-of-Staff who facilitated the collaborative efforts, and Laurel Sayer ("Sayer"), Simpson's Idaho staff member responsible for environmental issues in the state. The second set was for those stakeholders who participated in the four group collaborative meetings held in February 2001, June 2001, July 2002, and September 2005 (where at least two of the four stakeholder groups identified by Slater as necessary to the collaboration participated) (the "Combined Collaborative Meetings"). The third set was for those individual stakeholders who did not participate in the Combined Collaborative Meetings but interacted directly with Simpson, Slater, or Sayer. The interview questions for all interviewees were designed to elicit information directly relating to the collaborative actions taken or attempted in which each personally participated.

The interview questions for Slater and Sayer inquired into their preparation for CIEDRA collaborative efforts including advance preparation, the collaborative system or outline they set up, and the stakeholders and how they were chosen to participate. Next they were asked about the four Combined Collaborative Meetings, specifically who was involved, why they were chosen to participate, what was done and accomplished at the meetings, the values and interests identified by the participants, and decisions that were made in the meetings. They were then asked about other meetings or contacts they had with individuals or groups not participating in the Combined Collaborative Meetings.

Individuals who participated in the Combined Collaborative Meetings were asked to identify their stakeholder group and describe actions each group/person had taken relating to CIEDRA. Detailed questions followed about each meeting in which the interviewee participated to determine who the other participants were, who organized and facilitated the meeting, what actually happened at the meeting, and the meeting's perceived effectiveness. Each interviewee was asked to define collaboration, including the different elements of collaboration (e.g., who should participate, whether face-to-face meetings were required, how many meetings were needed, how long the collaborative efforts needed to last, whether there needed to be any structure or organization) and then asked to subjectively calculate whether or not they or their group participated in enough collaborative activities so that they could say they participated meaningfully in collaboration.

The interviewees who did not participate in the Combined Collaborative Meetings were asked to identify their stakeholder group, whether they had worked with any other organization, group, public official, interest groups, advocacy groups, policy actors, or other individuals on the CIEDRA campaign, and who they worked most closely with and why. They were specifically asked about their contacts or communications with Simpson, Slater, or Sayer. They were also asked to define collaboration and whether they thought they participated in enough collaborative activities so that they could say they also participated meaningfully in the collaboration. 
Six of the eleven individuals who attended one or more of the Combined Collaborative Meetings, representing the Idaho Conservation League (wilderness proponent), the BlueRibbon Coalition (motorized recreationists), The Wilderness Society (wilderness proponent), the Idaho State Snowmobile Association (motorized recreationists), and the Treasure Valley Trail Machine Association (motorized recreationists) were interviewed. Interviews with the ranchers and county commissioners that participated in the Combined Collaborative Meetings did not occur. However, a member of the Idaho Cattle Association and a Blaine County commissioner, both who participated in individual meetings with Slater, were interviewed. The remaining participants in the Combined Collaborative Meetings either failed to return multiple messages requesting their participation or indicated they would participate but then never provided a day and time for the interview.

In addition, eight other individuals who did not participate in the Combined Collaborative Meetings were interviewed. They represented disability advocates, the Sawtooth Society, the Idaho Conservation League, the International Mountain Biking Association, Idaho Outfitters and Guides Association, Backcountry Horsemen of Idaho, Blaine County (Idaho), and the Idaho Cattle Association, all of which had individual contacts with Simpson, Slater, or Sayer relating to CIEDRA. These individuals were chosen to round out the panoply of different stakeholder groups.

All interviews were completed during the first quarter of 2014 by telephone (with the exception of one in-person interview), were recorded, and notes were taken of the interview. All interviewees consented to their interview and granted permission to be named and have information they provided set out in subsequent articles.

It is believed that the interviewees represented a fair cross-section of stakeholder user groups and that the individuals interviewed were a fair representation of individuals comprising members of the stakeholder groups. ${ }^{\text {ii }}$

\section{Findings}

Slater (personal communication, 2014) himself identified the four broad categories of stakeholder groups to include in the collaboration Simpson desired. These were wilderness proponents, local ranchers, two local Idaho counties bordering the Boulder-White Clouds (Custer and Blaine), and motorized recreationists. Slater had prior knowledge of wilderness proponents from his previous work in Oregon with U.S. House of Representative Walden's (R-OR) office and public lands use legislation there, while Sayer had worked previously with Idaho ranchers and motorized recreationists. Using their personal knowledge of groups previously involved in similar type issues, Slater and Sayer decided which stakeholder groups and individuals from those groups would be involved and purposefully excluded some groups (e.g., Western Watersheds Project and Carole King's NREPA Network) that they thought would prevent resolution of the issues (L. Slater, personal communication 2014; L. Sayer, personal communication 2014). Other than this general knowledge of various groups, no formal or informal stakeholder analysis was ever performed (L. Slater, personal communication 2014; L. Sayer, personal communication 2014). To represent the four stakeholder groups Slater chose an individual who was both a rancher and Custer County 
Commissioner, the Idaho Conservation League and The Wilderness Society (both of which had spoken directly with Simpson and had indicated a willingness to work to pass CIEDRA), the Idaho State Snowmobile Association, and The BlueRibbon Coalition.

Slater and Sayer also reached out to other groups and individuals. Slater had more than 200 meetings or communications with individuals or groups about CIEDRA and Sayer had approximately 100 such meetings or communications (L. Sayer, personal communication, 2014; L. Slater, personal communication, 2014). However, only four stakeholder groups were invited to the four Combined Collaborative Meetings. Even then, not every group was represented in each of the four meetings. Of the eleven individuals representing the four groups, one participated in all four of the meetings, one participated in three, five participated in just two meetings, and four participated in a single meeting (Lee, 2015).

In February of 2001, Slater held the first of the four Combined Collaborative Meetings, attended by representatives of all four stakeholder groups, which he referred to as an initial conceptual discussion. Specific stakeholders invited to participate were the BlueRibbon Coalition, the Idaho State Snowmobile Association (later represented by the Idaho Recreation Council), the Idaho Conservation League, The Wilderness Society, a Custer County rancher and attorney, and a Custer County rancher who was at the time a Custer County Commissioner. In this meeting the discussion was general, with participants taking turns talking about what each wanted and what they didn't want.

Five months later, in June of 2001, Slater, Sayer, and representatives from the Idaho State Snowmobile Association, the BlueRibbon Coalition, the Idaho Conservation League, and The Wilderness Society met in Hailey, Idaho, for the second of the four Combined Collaborative Meetings, in what Slater characterized as a CIEDRA Exploratory Meeting of Principles (L. Slater, personal communication, 2014). Thus, this meeting involved only two of the four stakeholder groups - motorized recreationists and wilderness proponents. At the beginning of the meeting, there were "walls" up between the participants, but eventually individuals from the two groups began talking and that they "broke the ice" (L. Sayer, personal communication, 2014). It was anticipated that each of the participants would go back and discuss with their individual groups the idea that Simpson was putting together specific legislation for the Boulder-White Clouds area and that they should decide what they wanted and needed out of CIEDRA. The meeting was described as "not very useful" because the debate devolved into a discussion as to why there should be any more wilderness. Slater was described as very discouraged after this meeting (L. Sayer, personal communication, 2014).

Thirteen months later, in July of 2002, Slater and representatives of the Idaho Conservation League, The Wilderness Society, and the Magic Valley, Idaho, and Treasure Valley Trail Machine Associations met in Simpson's Boise office for the third of the Combined Collaborative Meetings, characterized again by Slater as a CIEDRA Meeting of Principles. This meeting also included some mountain bikers (mechanized groups) as the motorized groups had previously let the mountain bikers know of the collaborative efforts. When motorized corridors were identified on maps, the participants' differences of opinion over the closure of some motorized corridors was clear and uncompromising (C. Collins, personal 
communication, 2014; C. Cook, personal communication, 2014; L. Kincannon, personal communication, 2014).

On September 1, 2004 three town hall meetings in towns directly impacted by CIEDRA were organized by Slater to allow citizen input on a written CIEDRA framework released by him three months earlier. Input was obtained in all three meetings from numerous individuals and groups, including those representative of all four of Slater's necessary stakeholder groups.

On October 8, 2004 Simpson introduced H.R. 5343 - Central Idaho Economic Development and Recreation Act of 2004 (CIEDRA), in the House for the first time. Among others, CIEDRA contained the following provisions (Simpson, 2010):

- Lands within the area that become wilderness (approximately 333,000 acres) would be managed as wilderness by the current managing district.

- $\quad$ Lands within the area that were not designated as wilderness would be managed by the same managing agency (e.g., Sawtooth National Recreation Area, Challis National Forest, and Challis Bureau of Land Management).

- Approximately 131,670 acres currently in "wilderness study" status would be released.

- $\quad$ The 4th of July Basin would remain open to snowmobiling from Blackman Peak to Patterson Peak (West Side), including the 4th of July Basin. The 4th of July Basin would be closed to all other motorized or mechanized activities. A wheelchair accessible trail would be established to 4th of July Lake from the Phyllis Lake cutoff.

- Three OHV motorized recreation parks would be developed near Boise, Twin Falls, and Pocatello. Land for the parks would be transferred from the BLM to the State of Idaho. Each park would include a beginner track to teach safe, responsible riding techniques as well as advanced riding techniques. Funding for this proposal would come from Off-Highway Vehicle Fund monies as developed for this proposal.

- The proposed wilderness boundary on the east side of the private lands on the East Fork Road would be moved to the ridgeline on the east side of the East Fork of the Salmon River.

- The proposed creation of the Hemingway Wilderness Area in Blaine County, including a description of areas included in the wilderness and areas not included in the wilderness.

- That there would not be "buffer zones" or a "protective perimeter" created around the wilderness so that uses allowed outside the wilderness could continue even though those uses could be seen or heard within the wilderness.

- Federal lands in the area would be transferred to local counties for economic purposes.

The $108^{\text {th }}$ congressional session ended without action on the bill. Simpson reintroduced it in the $109^{\text {th }}$ congressional session as H.R. 2514 on May 19, 2005.

On September 26, 2005, the last of the four Combined Collaborative Meetings occurred. The participants went on what Slater referred to as a field tour in the Boulder-White Clouds area. Included with the group were a local rancher and Custer County Commissioner (a different 
individual than the one who participated in the first of the Combined Collaborative Meetings), and representatives from The Wilderness Society, the Idaho Conservation League, and the Idaho and Treasure Valley Trail Machine Associations. While some of the participants found the field tour to be useful, others felt that it was a waste of time and only served to create more opposition (C. Cobbley, personal communication, 2014).

Both Slater and Sayer readily agreed that throughout the entire process, their actions were more in line with "shuttle diplomacy" rather than collaboration (L. Sayer, personal communication, 2014; L. Slater, personal communication, 2014). This was echoed by nearly all of the interviewees.

Thus, it is apparent from the interviews that there were only four collaborative meetings over a period of approximately four and one-half years where there were representatives from at least two of the four stakeholder groups that Slater had identified as necessary to the collaborative process (Lee, 2015). Table 1 sets forth the four meetings and which stakeholder groups participated in each meeting.

Table 1. Four stakeholder groups and representatives from each group participating in the four Combined Collaborative Meetings

\begin{tabular}{|l|c|c|c|c|}
\hline & $\begin{array}{c}\text { Feb. 2001 } \\
\text { (Meeting) }\end{array}$ & $\begin{array}{c}\text { June 2001 } \\
\text { (Meeting) }\end{array}$ & $\begin{array}{c}\text { July 2002 } \\
\text { (Meeting) }\end{array}$ & $\begin{array}{l}\text { Sept. 2005 } \\
\text { (Field Trip) }\end{array}$ \\
\hline Ranchers & X & & & X \\
\hline Local Govt. & X & & & X \\
\hline Motorized Recreationists & BRC & BRC & BRC & TMA \\
& ISSA & ISSA & TMA & TMA \\
\hline Wilderness Proponents & ICL & ICL & ICL & ICL \\
& TWS & TWS & TWS & TWS \\
\hline
\end{tabular}

BRC - BlueRibbon Coalition

ISSA - Idaho State Snowmobile Association

TMA - Trail Machine Association (three different clubs represented) ICL - Idaho Conservation League

TWS - The Wilderness Society

\section{Discussion}

The evidence elicited through the interviews indicates that there was no sustained collaborative decision making process, but instead Simpson's efforts devolved into shuttle diplomacy. ${ }^{\text {iii }}$

\subsection{Preparatory Step}

Slater and Sayer indicated that they did not undertake a broad overview of the process in order to determine the scope of the issue and to create the appropriate collaborative process itself. Simpson had defined the problem/issue as the need to protect ranchers from unnecessary lawsuits related to grazing rights, clarify public land uses by legislation, provide an economic boost to local counties, and create new wilderness. Stakeholders were simply apprised of the issues that Simpson was looking to resolve but felt that they did not play a part in the problem/issue definition, possibly as a result of the stakeholders' lack of 
ownership of the process (Carpenter, 1999). Some stakeholders questioned the extent that their input was ever considered (C. Collins, personal communication, 2014; S. Mitchell, personal communication, 2014; L. Slater, personal communication, 2014). One recurring problem was that various stakeholders did not believe there was a problem or issue needing to be resolved (C. Collins, personal communication, 2014; L. Kincannon, personal communication, 2014; S. Mitchell, personal communication, 2014). There was no stakeholder analysis undertaken (L. Slater, personal communication, 2014; L. Sayer, personal communication, 2014) and only four general stakeholder groups were identified to participate in the collaboration meetings, and in only two of the four meetings were all four groups represented (complicated by the fact that the representatives from the different stakeholders groups were not always the same individuals).

It is possible, however, that even without a stakeholder analysis, many of the necessary stakeholders under the Rule of Five (Clemons \& McBeth, 2009) were chosen for participation in the four meetings. These would have included ranchers (there are six-generation ranchers operating in the area), wilderness proponents (the Idaho Conservation League and the Wilderness Society), Custer and Blaine County Commissioners, motorized recreationists (the BlueRibbon Coalition and the state and local Trail Machine Associations), winter motorized recreationists (the Idaho State Snow Machine Association), and non-motorized recreationists (the Idaho Mountain Biking Association who was brought in by the Trail Machine Association groups, but which did not participate in any Combined Collaborative Meetings).

If, however, Simpson, Slater, or Sayer would have used a Power vs. Interest grid (Bryson et al., 2002; Eden \& Ackermann, 1998), they could have identified stakeholders with their individual levels of power and interest in the dispute. A Stakeholder Influence Diagram (Bryson el al., 2002; Eden \& Ackermann, 1988; Finn, 1996) could have then been created highlighting the multiple influence relationships among the stakeholders. Finally, a "Bases of Power - Directions of Interest" diagram (Bryson et al., 2002) could have been created to indicate the sources of power upon which shareholders can draw and the goals or interests the stakeholders seek to achieve as a visual representation of commonalities of interests across stakeholders or stakeholder subgroups that could indicate natural or possible coalitions. Alternatively, a stakeholder map (Clemons \& McBeth, 2009) could have been created to identify characteristics of the individual stakeholders to determine whether they were internal or external stakeholders, whether they were cooperating or opposing the policy, the values and objectives that shaped stakeholders' attitudes toward the issue, the salience of the issue to the stakeholders, the stakeholders' power to adopt and power to implement, who the stakeholders influenced, and who influenced the stakeholders. Under these different modes of stakeholder analyses, stakeholders, their positions, power, and influence could have been identified and steps could have been taken to strategically attempt to ameliorate stakeholder opposition or lack of support, create winning coalitions, and strengthen support.

Various stakeholders also identified a significant impediment to collaborative success. Many groups were simply satisfied with how the area was being used and saw no need for a change. Without a "hammer" or threat to the motorized groups, representatives from the Idaho State 
Snowmobile Association, Idaho Conservation League, and The Wilderness Society all correctly surmised that the motorized groups would not move off of their positions (C. Gehrke, personal communication, 2014; L. Kincannon, personal communication, 2014; S. Mitchell, personal communication, 2014). Furthermore, motorized and mechanized recreationists were unwilling as a whole to consent to more wilderness being designated under CIEDRA because some roads or trails would be closed. This may reflect a perception of closure as an overall loss (consisting of loss of access and use by their groups) rather than a win (resulting from solidification of existing use and access). Quattrone and Tversky (1988) suggest that loss aversion can impede bargaining and negotiation because parties may view their own concessions as losses that loom larger than any gains realized by concessions of adversaries. Individuals tend to remember their defeats more than they remember their victories (Sabatier \& Weible, 2007). Simpson was never able to counter this impediment and view. Finally, in this preparatory step, there is no evidence that an estimate of probably stakeholder objectives and alternatives was made.

\subsection{Participatory Steps}

During the participatory part of the process objectives and values of stakeholders are defined, performance measures are determined, and alternatives are developed, analyzed, and selected. There is either no or minimal evidence that these steps were followed. For instance, there was no evidence that objectives and values were systematically defined by the stakeholders. There is some evidence that they were discussed, but participants hold differing views of the extent and effectiveness of the discussion. For instance, motorized groups perceived wilderness proponents simply saying "because" when asked about the reasons (the "whys") for their demands (C. Cobbley, personal communication, 2014). Motorized group representatives indicated that they did not believe that the wilderness proponents actually listened to them $(\mathrm{C}$. Cobbley, personal communication, 2014).

There is little evidence that alternatives were developed, analyzed, and selected by the stakeholders. Interviewees varied in their perception of alternative creation. These perceptions ranged from not developing alternatives with the stakeholders simply being told what they would do and get (L. Kincannon, personal communication, 2014), being told that "you can do this or that but you can't do both" (C. Cobbley, personal communication, 2014), to shuttle diplomacy (C., Gehrke, personal communication, 2014). One representative remembered feeling that the collaboration only lasted until CIEDRA was first introduced in 2014 and after that time, it became simple negotiation on the fringes (L. Kincannon, personal communication, 2014). Multiple interviewees indicated that ideas were presented to them by Simpson or his staff with the expectation that they and their group would think about the proposal and get back to them (L. Kincannon, personal communication, 2014; L. Sayer, personal communication, 2014). No stakeholder interviewee mentioned meetings where alternatives were developed or analyzed. All interviewees indicated that they informed Simpson, Slater, or Sayer what they wanted, but they were not sure that this information had been communicated to other stakeholders. Some groups felt that they were not listened to in any event. At this stage of the process, at best, proposals and responses were made by way of shuttle diplomacy with little or no feedback, and at worst, stakeholders were simply told what 
was going to happen.

Part of the selection process involves trade-offs. Because of the numerous interests at play in the Boulder-White Clouds area, value trade-offs are inevitable and involve consideration of what one would give up on one objective in order to achieve another (Gregory et al., 2012). The trade-off process can be extremely difficult (Abigail \& Cahn, 2011; Fox \& Miller, 1996; Nie, 2003; Weber \& Khademian, 2008), yet the personal relationships created between the stakeholders can in time lead to trust, learning, and sharing in the process, all that lead to the trade-offs requisite to resolution (Irvin \& Stansbury, 2004; King, Feltey, \& Susel ,1998; Stevens, 2006). In order to create these personal relationships, it is necessary for the stakeholders to work together over a period of time. This may have been the biggest obstacle facing the collaboration. The stakeholders never took the time together to develop this type of relationship. Motorized recreationists felt that the wilderness proponents never actually heard what they were saying, even perceiving that though meetings were held, stakeholders never did sit down and really talk. The stakeholders never participated in the trade-off process as there was not one.

Almost without exception, when asked, interviewees identified the important necessary steps for collaboration, including the numerous meetings within a short time frame needed to establish the necessary rapport needed for collaboration to succeed. However, none of them provided any information of they actually participated in these steps. Interestingly, the majority of the interviewees personally perceived that they had personally significantly participated in collaboration, even when they did not collaborate under their own definition of collaboration.

\subsection{Why Collaboration Was Not Used}

For all the talk of collaboration, one might wonder why it was not actually utilized in the CIEDRA process. There are a number of possibilities why it was not used.

Prior to working for Simpson, Slater indicated that he worked for U.S. Rep. Greg Walden (ROR) and was closely involved in the Steens Mountain Cooperative Management and Protection Act of 2000 (L. Slater, personal communication, 2014). This legislation was prompted by Pres. Clinton's intent to designate a monument covering the area under the Antiquities Act (16 U.S.C. $\S \$ 431-433$ ). Over a period of twelve months, two citizen committees and then an ad hoc collection of legislative staffers, struggled with ideas to protect Steens Mountain (Marlett, 2000). These committees and staff members were not able to reach consensus. Eventually four individuals, two ranchers and two wilderness proponents, were chosen to work together with the idea that they might actually be able to finalize a deal (Kerr, 2006). Over a two-day negotiation marathon the four individuals hammered out a deal. Ultimately, with the support of Oregon's governor, Oregon's congressional delegation, and the Secretary of the Interior, the Act passed and was signed into law by President Clinton.

Slater seems to have followed somewhat the same format for CIEDRA in the beginning. The process started out with gathering input from numerous sources, some from meetings and others with individual contacts. These meetings included representatives from the four major 
stakeholder groups. When consensus did not occur in the first two Combined Collaborative Meetings, the number of meetings and participants was reduced and shuttle diplomacy ensured. A major difference, however, between CIEDRA and Steens Mountain was the fact that there was simply not the sheer number of joint meetings as in the Sheens Mountain efforts. Further, there was no negotiation marathon between stakeholders in an attempt to reach consensus. This may be the result of the motorized group resisting so forcefully that Slater deemed it not productive to meet jointly. It may also simply be the result of the unique dynamics of the Steens Mountain activity - monument status was going to happen unless legislative action was taken (Lee, 2017). The "monument hammer" was in place and ready to fall, whereas with CIEDRA there was no such threat. ${ }^{\text {iv }}$

Pralle (2006) enunciates clear strategies for expanding and containing issue definition, policy actors, and institutions and venues. Underlying these strategies is the assumption that whenever any participant in the process takes action to expand or contain, other participants must reevaluate and adjust their strategy as necessary to counteract the action. Failure to adequately do this results in failure to achieve the desired outcome. In a real sense, it is similar to a chess match where current and future moves are constantly considered, analyzed, and evaluated. Similarly, good strategic thinking considers, analyzes, and evaluates every participant's past, current, and anticipated future action, including one's own actions. "It is fair to say that the game of politics may be getting more complicated, thus putting a premium on good strategic thinking" (Pralle, 2006, p. 230).

In this instance, Simpson and his staff appeared to either not anticipate or recognize the extreme opposition by motorized and mechanized groups (Mitchell, personal communication 2014; Cook, personal communication 2014), and in any event, did not adjust their strategy to counteract the opposition. Motorized recreationists indicated that they were very successful in getting the word out about the negative aspects of CIEDRA as they perceived it. The results of the poll they commissioned showing opposition to CIEDRA were heralded throughout the local area and the state without any apparent, successful counter from Simpson.

It does not appear that this strategic thinking exercise took place as the CIEDRA process unfurled. It appears that reactive shuttle diplomacy was also the method to deal with actions or positions taken by stakeholders.

It is always easy to state at a theoretical level what should be done in any given set of circumstances. Unfortunately, real world issues may negatively affect any collaboration. These issues include, but are not limited to, time constraints, costs of participation, and loss of control at federal congressional level.

With any collaborative efforts, it takes time to go through the process. Unfortunately, time is limited and many decisions are made in a reactive mode rather than a proactive mode (Clemons \& McBeth, 2009). For instance, it takes time to gather information needed to proceed (with both the problem of having too little and too much information), and to prepare for and participate in meetings. Those involved have other things that need their attention and time. For instance, the Custer County rancher and County Commissioner simply did not have time to attend the last three Combined Collaborative Meetings. In addition, once a bill gets 
introduced, stakeholders lose control. The congressional process itself is complex and lengthy.

\section{Conclusion}

Simpson did not use collaborative decision making as defined herein with CIEDRA. While he may have started the process with this process as the goal, it quickly devolved into shuttle diplomacy. There were a total of only four Combined Collaborative Meetings over four and one half years involving those groups identified by Slater as "principals" in the process. Further, there was not consistent attendance by the principals in those four meetings. It appears that Slater gave up too soon on the collaborative decision making process and moved to shuttle diplomacy. It may be that Simpson and Slater simply decided to pursue shuttle diplomacy after seeing such a divide between the CIEDRA principals. However, effective collaborative decision making for environmental and sustainable development policies requires stakeholders willing to invest in a lengthy process over many meetings (Gregory et al., 2012). As stakeholders work together, trust can be generated, and a desire to continue to work together may be created (Thomson et al., 2009). The stakeholders do not seem to have been given the chance in this case. The result was failure.

One should not necessarily fault the move to shuttle diplomacy as at the time, the idea of collaborative decision making as described in the literature was a newer conceptual process and shuttle diplomacy was a tried methodology. Still, the failure to continue holding meetings with the CIEDRA principles with a much shorter time in-between meetings prevented the collaborative decision making described herein to take place. Collaborative decision making simply cannot work when the stakeholders do not meet and work together.

\section{References}

Abigail, R. A., \& Cahn, D. (2011). Managing Conflict through Communication (4th ed.) Boston, MA: Allyn \& Bacon. Antiquities Act. 16 U.S.C. $§ 431-433$.

Bardach, E. (2009). A Practical Guide for Policy Analysis - the Eightfold Path to More Effective Problem Solving (3rd ed.). Washington, D.C.: CQ Press.

Baumgartner, F. R., \& Jones, B. D. (1993). Agendas and Instability in American Politics. Chicago: University of Chicago Press.

Boscarino, J. E. (2009). Surfing for Problems: Advocacy Group Strategy in U.S. Forestry Policy. The Policy Studies Journal, 37, 415-434.

https://doi.org/10.1111/j.1541-0072.2009.00321.x

Bryson, J. M., Cunningham, G. L., \& Lokkesmoe, K. J. (2002). What to do When Stakeholders Matter: The Case of Problem Formulation for the African American Men Project of Hennepin County, Minnesota. Public Administration Review, 62, 568-586. https://doi.org/10.1111/1540-6210.00238

Carpenter, S. (1999). Choosing Appropriate Consensus Building Techniques and Strategies. In L. Susskind, S. McKearnan, \& J. Thomas-Larmer (Eds.), The Consensus Building 
Handbook (pp. 61-97). Thousand Oaks, CA: Sage Publications, Inc.

https://doi.org/10.4135/9781452231389.n2

Chapin, F. S., Trainor, S. F., Huntington, O., Lovecraft, A. L., Zavaleta, E., Natcher, D. C., et al (June 2008). Increasing Wildfire in Alaska's Boreal Forest: Pathways to Potential Solutions of a Wicked Problem." BioScience, 58, 531-540. https://doi.org/10.1641/B580609

Clemons, R. S., \& McBeth, M. K. (2009). Public Policy Praxis. A Case Approach for Understanding Policy and Analysis (2nd ed.). San Francisco, CA: Pearson.

Daniels, S. E., \& Walker, G. B. (2001). Working through Environmental Conflicts: the Collaborative Learning Approach. Westport, CT: Praeger.

Domenici, K., \& Littlejohn, S. W. (2001). Mediation: Empowerment in Conflict Management, (2nd ed.). Long Grove, IL: Waveland Press, Inc.

Dunn, W. N. (2004). Public Policy Analysis: An Introduction (3rd ed.). Upper Saddle River, NJ: Prentice Hall.

Eden, C., \& Ackermann, F. (1998). Making Strategy: The Journey of Strategic Management. Thousand Oaks, CA: Sage Publications.

Finn, C. B. (1996). Utilizing Stakeholder Strategies for Positive Collaborative Outcomes. In C. Huxham (Ed.), Creating Collaborative Advantage (pp. 152-164). Thousand Oaks, CA: Sage Publications.

Fisher, R., \& Ury, W. (1991). Getting to yes: Negotiation agreement without giving in (2nd ed.). New York: Penguin Books.

Fox, C. J., \& Miller, H. T. (1996). Postmodern Public Administration: Toward Discourse. Thousand Oaks, CA: Sage.

Gregory, R., Failing, L., Harstone, M., Long, G., McDaniels, T., \& Ohlson, D. (2012). Structured Decision Making: A Practical Guide to Environmental Management Choices (1st ed.). West Sussex: Wiley-Blackwell.

Gunderson, L. H. (1999). Assessing for understanding in complex regional systems. In K. N. Johnson, F. J. Swanson, M. Herring, \& S. Greene (Eds.), Bioregional Assessments: Science at the Crossroads of Management and Policy. Washington, DC: Island Press.

Hogwood, B. W., \& Gunn, L. A. (1984). Policy analysis for the real world. London: Oxford University Press.

Hurley, P. T., \& Walker, P. A. (2004). Whose vision? Conspiracy theory and land use planning in Nevada County, California. Environment and Planning, 36, 1579-1547.

https://doi.org/10.1068/a36186

Irvin, R., \& Stansbury, J. (2004). Citizen Participation in Decision Making: Is It Worth the Effort? Public Administration Review, 64, 55-65.

https://doi.org/10.1111/j.1540-6210.2004.00346.x 
Keeney, R. L. (1992). Value-Focused Thinking A Path to Creative Decisionmaking. Cambridge, MA: Harvard University Press.

Keeney, R. L. (2002). Common Mistakes in Making Value Trade-offs. Operations Research, 50, 935-945. https://doi.org/10.1287/opre.50.6.935.357

Kerr, Andy. (2006). The Steens Mountain Cooperative Management and Protection Act of 2000 (Oregon). A Western Governors’ Association White Paper.

King, C. S., Feltey, K. M., \& Susel, B. O. (1998). The Question of Participation: Toward Authentic Public Participation in Public Administration. Public Administration Review, 58, 317-326. https://doi.org/10.2307/977561

Kingdon, J. (1984/1995). Agendas, Alternatives, and Public Policies (2nd ed.). New York: HarperCollins College Publishers.

Lee, E. (2015). From CIEDRA to Wilderness - An unsuccessful attempt at collaboration in the Boulder-White Clouds. The Blue Review, October 28, 2015. Retrieved on October 28, 2015 at https://thebluereview.org/from-ciedra-to-wilderness-in-boulder-white-clouds.

Lee, E. (2017). The Threat of Monument Designation as a Technique for Successful Wilderness Legislation. Paper presented at the $59^{\text {th }}$ Annual Conference of the Western Social Science Association held on April 12-15, 2017.

Ludwig, D., Mangel, M., \& Haddad, B. (2001). Ecology, Conservation, and Public Policy. Annual Review of Ecology and Systematics, 32, 481-517.

https://doi.org/10.1146/annurev.ecolsys.32.081501.114116

Marlett, B. (2000). Clinton signs Steens Protection Act! Nation's first cow-free desert wilderness among gains in bill. Desert Ramblings, (Fall 2000). Retrieved on June 15, 2014 at http://onda.org/publications/newsletter/archived-newsletters-pre- 2009/Fall\%2000.pdf.

McBeth, M., Lybecker, D., \& Garner, K. (2010). The Story of Good Citizenship: Framing Public Policy in the Context of Duty-Based versus Engaged Citizenship. Politics and Policy, 38, 1-23. https://doi.org/10.1111/j.1747-1346.2009.00226.x

McBeth, M., \& Shanahan, E. (2004). Public opinion for sale: The role of policy marketers in Greater Yellowstone policy conflict. Policy Sciences, 37, 319-338.

https://doi.org/10.1007/s11077-005-8876-4

Nie, M. A. (2003). Drivers of natural resource-based political conduct. Policy Sciences, 36, 307-341. https://doi.org/10.1023/B:OLIC.0000017484.35981.b6

Pearce, W. B., \& Littlejohn, S. W. (1997). Moral Conflict: When Social Worlds Collide. Thousand Oaks, CA: Sage Publications, Inc.

Pralle, S. B. (2006). Branching Out Digging In - Environmental Advocacy and Agenda Setting. Washington, DC: Georgetown University Press.

Quattrone, G. A., \& Tversky, A. (1988). Contrasting rational and psychological analyses of 
political choice. American Political Science Review, 82, 719-736.

https://doi.org/10.2307/1962487

Rittel, H., \& Webber, M. (1973). Dilemmas in a General Theory of Planning. Policy Sciences, 4, 155-169. https://doi.org/10.1007/BF01405730

Rochefort, D. A., \& Cobb, R. W. (1993). Problem Definition, Agenda Access, and Policy Choice. Policy Studies Journal, 21, 56-71.

https://doi.org/10.1111/j.1541-0072.1993.tb01453.x

Rutherford, M. B., Gibeau, M. L., Clark, S. G., \& Chamberlain, E. C. (2009). Interdisciplinary Problem Solving Workshops for Grizzly Bear Conservation in Banff National Park, Canada. Policy Sciences, 42, 163-187.

https://doi.org/10.1007/s11077-009-9075-5

Sabatier, P. A., \& Jenkins-Smith, H. (1988). An Advocacy Coalition Model of Policy Change and the Role of Policy Oriented Learning Therein. Policy Sciences, 21, 129-168.

https://doi.org/10.1007/BF00136406

Sabatier, P. A., \& Jenkins-Smith, H. (1993). Policy Change and Learning: An Advocacy Coalition Approach. Boulder, CO: Westview Press.

Sabatier, P. A., \& Jenkins-Smith, H. (1999). The Advocacy Coalition Framework: An Assessment. In P. Sabatier (Ed.), Theories of the Policy Process. Boulder, CO: Westview Press.

Sabatier, P. A., \& Weible, C. M. (2007). The Advocacy Coalition Framework: Innovations and Clarifications. In P. Sabatier (Ed.), Theories of the Policy Process (2nd ed., pp.189-220). Boulder, CO: Westview Press.

Schmitt, R. (2011). Dealing with Wicked Issues: Open Strategizing and the Camisea Case. Journal of Business Ethics, 96, 11-19. https://doi.org/10.1007/s10551-011-0938-2

Schmidtz, D. (2000). Natural Enemies: An anatomy of environmental conflict. Environmental Ethics, 22, 397-408. https://doi.org/10.5840/enviroethics20002245

Schwarz, N. (2007). Retrospective and Concurrent Self Reports: The Rationale for Real Time Data Capture. In S. Stone, S. Shiffman, A. Atienze, \& L. Nebeling (Eds.), The Science of Real Time Data Capture: Self Reports in Health Research (pp. 11-26). New York: Oxford University Press.

Shindler, B. A., \& Cramer, L. A. (1999). Shifting public values for forest management: Making sense of wicked problems. Western Journal of Applied Forestry, 14, 28-34.

Simpson, M. (2010). CIEDRA: An Idaho Solution to Idaho Land Management. Retrieved on March 1, 2014 at http://simpson.house.gov/news/documentsingle.aspx ?DocumentID=198795

Stevens, S. M. (2006). Activist Rhetorics and the Struggle for Meaning: The Case of 'Sustainability' in the Reticulate Public Sphere. Rhetoric Review, 25, 297-315. https://doi.org/10.1207/s15327981rr2503_4 


\section{Macrothink}

Environmental Management and Sustainable Development

ISSN 2164-7682

2017, Vol. 6, No. 2

Stone, D. (2002). Policy Paradox: The Art of Political Decision Making Revised Edition. New York, New York: W. W. Norton and Company.

Thomson, A. M., Perry, J. L., \& Miller, T. K. (2009). Conceptualizing and Measuring Collaboration. Journal of Public Administration Research, 19, 23-56.

https://doi.org/10.1093/jopart/mum036

True, J. L., Jones, B., \& Baumgartner, F. (2007). Punctuated-Equilibrium Theory: Explaining Stability and Change in Public Policy Making. In P. Sabatier (Ed.), Theories of the Policy Process (2nd ed., pp. 97-116). Boulder, CO: Westview Press.

Van de Kerkhof, M. (2006). Making a Difference: On the Constraints of Consensus Building and the Relevance of Deliberation in Stakeholder Dialogues. Policy Sciences, 39, 279-299. https://doi.org/10.1007/s11077-006-9024-5

Weber, E. P., \& Khademian, A. M. (2008). Wicked Problems, Knowledge Challenges, and Collaborative Capacity Builders in Network Settings. Public Administration Review, 68, 334-349. https://doi.org/10.1111/j.1540-6210.2007.00866.x

Zahariadis, N. (2007). The Multiple Streams Framework: Structure, Limitations, Prospects. In P. Sabatier (Ed.), Theories of the Policy Process (2nd ed., pp. 65-92). Boulder, CO: Westview Press.

\footnotetext{
${ }^{\mathrm{i}}$ It is noted that with the continuing failure to pass CIEDRA, there was a broad-based movement for designation of the area as a national monument by President Obama under his authority pursuant to the Antiquities Act (16 USC $\S \S 431-433$ ). The subsequent indication by the Obama administration that it would designate the area a national monument renewed the legislative push by Simpson which ultimately ended with the enactment of the Sawtooth National Recreation Area and Jerry Peak Wilderness Additions Act by President Obama's signature on August 7, 2015 (Lee 2015). The analysis in this article does not consider any collaborative efforts taken after the Obama administration's indication of monument status consideration for the area.

ii All interviewees are identified in in-text citations by name and year of interview. For ease of reading, the month is not given, although all interviews took place during the first quarter of 2014. They are not listed in the references section.

iii It is not known to what extent that Simpson, Slater, and Sayer had any substantive familiarity with the steps outlined herein.

iv This "monument hammer" was eventually poised to come down as John Podesta, senior counsel for President Obama, indicated that a monument covering the Boulder-White Clouds area would be designated if Simpson was not successful in passing legislation.
}

\section{Copyright Disclaimer}

Copyright for this article is retained by the author(s), with first publication rights granted to the journal.

This is an open-access article distributed under the terms and conditions of the Creative Commons Attribution license (http://creativecommons.org/licenses/by/3.0/). 